\title{
From Source to Sink: How Linking Upstream Fluvial Processes to Mangrove Sedimentation Can Improve Mangrove Management Strategies
}

\author{
Shannon Jones* \\ Department of Geography and the Environment, University of Denver, USA
}

Submission: July 21, 2020; Published: August 13, 2020

Corresponding author: Shannon Jones, Department of Geography and the Environment, University of Denver, USA

\begin{abstract}
Although recent attention has been given to accelerated sea level rise (SLR), anthropogenic activity disrupts incoming flow and sediment critical to maintaining the mangrove ecosystem. Deforestation and conversion to agriculture and urban landscapes can increase sedimentation rates of mangroves. Excess sedimentation of mangroves causes upland species invasions, aerial root burial, and tree die-off. Conversely, dams and diversion of flow decrease the influx of sediment into mangroves and limits the effectiveness of mangroves to respond to SLR. Predicted increases in precipitation, erosion, and flooding due to climate change further exacerbates these issues, yet current hydrologic models do not fully incorporate the interrelations and amplification of these processes from anthropogenic activity and climate change. Despite significant literature of fluvial, coastal, and marine processes and their effects on mangroves, there is limited understanding of the complex integrations and interactions between these processes and their effect on mangrove sedimentation. Although improving, hydrometeorological monitoring is often spatially and temporally limited, therefore extracting mangrove sediment records can provide information on sediment accretion rates in relation to SLR. Additionally, hydrologic models, created primarily by and for temperate environments, often do not effectively model tropical processes, seasonal effects of rainfall, or compound fluvial and coastal flooding from tropical cyclones. The lack of integrated hydrologic modelling and monitoring leaves local communities ill-prepared to make effective management decisions. Globally, to make significant advancement towards effective mangrove management, upstream river management is needed in addition to limitations on mass tourism, deforestation, and rapid development in areas hydrologically connected to the mangroves.
\end{abstract}

Kewords: Mangrove; Vulnerability; Erosion; Coastal Management; Sedimentation; SLR; Fluvial; Flooding

Abbreviations: SLR: Sea level rise

\section{Introduction}

Tropical and subtropical mangroves are among the most biologically productive ecosystems in the world [1,2]. They provide important ecosystem services, such as stabilizing and protecting shorelines from natural disasters, provide breeding grounds for numerous marine and riverine species, and sequester carbon [1]. Despite their ecological, biological, and economic value, mangroves are significantly degrading and declining at a faster rate than inland tropical forests and coral reefs, with only $6.9 \%$ protected under existing protected area networks [1,2]. Recent attention has been given to accelerated sea level rise (SLR) on the decline of mangrove forests [3-5]. However, disruption of upstream supply of fluvial flow and sediment have more extensive and immediate effects on mangrove survival rates [6-10].

The extent and health of mangroves rely on a balance of upstream fluvial processes and coastal processes to supply incoming sediment. Mangrove sediment accretion increases the surface elevation of mangroves which can help offset local SLR and protect coasts and adjacent land from erosion and storm surges [9]. However, rapid coastal and inland land use change alters upstream fluvial systems and shifts the balance of incoming sediment to mangroves. Thus, managing riverine sediment sources is critical for maintaining the long-term sustainability of mangrove ecosystems [11].

Although there is significant literature of fluvial, coastal, and marine processes and their effects on mangroves, there is limited understanding of the complex integrations and interactions between these processes and their effect on mangrove sedimentation. Furthermore, processes within mangrove estuaries that affect sediment accretion rates, such as sedimentation, suspension, accretion, erosion, and biologic activity, are not well modelled [9]. This creates significant challenges to modelling 
predicted changes and to effectively conserve and manage mangrove ecosystems. Therefore, there is an urgent need for improved modelling, monitoring, and management of fluvial processes linked to mangrove sediment accretion.

\section{Sedimentation vs Sediment Accretion}

While often used interchangeably, sedimentation is measured on a shorter timescale, often hours to days, and sediment accretion rates are measured over months to years [9]. Sediment accretion rates depend on sedimentation and resuspension and the shear strength of the deposited material that bind it more firmly in place [9]. There is also a lateral change in sedimentation rates, with the highest rates often occurring along the mouth of rivers. Sediment size also decreases with a decrease in flow velocity away from the riverbank into the mangroves $[12,13]$.

Anthropogenic changes have shorter-term implications for the long-term sustainability of mangroves $[11,14,15]$. Deforestation and upstream conversion to agriculture, aquaculture, mass tourism, and urban development can significantly increase the rate of sedimentation of mangroves [1,16-18]. Excess sedimentation negatively effects ecosystem productivity by reduced the vigor of mangrove trees, burial of aerial roots, tree die-offs, and invasion of upland species [9,19-21]. The increased freshwater inputs decrease salinity which can alter species composition in mangrove ecosystems [22].

Alternatively, dams, reservoirs, sand mining, and agricultural diversions can significantly reduce sediment supply to the mangroves and can cause subsidence [11,23]. Harbors, ports, and coastal structures also disrupt sediment supply [23]. Groundwater extraction and saltwater intrusion exacerbate the issue since more sediment is needed to counteract subsistence and SLR $[3,9,11,24]$. Increased SLR and subsistence cause landward retreat of mangroves; however, anthropogenic changes further inland limits the area in which mangroves can retreat, further threatening their survival [4, 25-27].

Natural processes, such as seasonality and tropical cyclones, also influence sedimentation and accretion rates, with lower rates during the dry season and higher rates during the rainy season [ 9 , 28]. Seasonal rainfall increases runoff, groundwater inflow, river flow, and sediment discharge. Predicted increases in precipitation rates from climate change increases these processes and could result in excess sediment accretion rates in the mangroves $[29,30]$.

Tropical cyclones often occur during the rainy season and can deliver large amounts of sediment to mangroves $[9,31]$. These lower frequency, high intensity events could be critical in maintaining mangroves in regions with less sediment inputs and higher subsistence rates [9,32-34]. Heavy rainfall from intense storm events cause surface runoff, subsurface flow, and river flooding. Simultaneous tides and storm surges, along with underlying conditions, can cause compound flooding that amplifies sea levels and leads to prolonged and widespread flooding along the coast and further inland [29,30,35].

Although incoming sediment is increased by large storm events, excess sedimentation and prolonged inundation can cause compression and lead to the decline of mangroves, which lowers surface elevation [9,36,37]. Moreover, large storms can affect erosion thresholds by lowering the shear strength of mangrove soils and increasing shear stress from waves and currents [9,38]. Predicted increases of intensity of flooding and tropical cyclones due to climate change is expected, further supporting the need for long-term monitoring and management of hydrologically connected rivers associated with mangroves [38].

Mangrove sediment records can be used to reconstruct the paleoenvironmental records of sea level and climate change fluctuations as well as mangrove sediment accretion rates and survival overtime $[9,25,28]$. In several locations, mangrove sediment records indicate mangrove accretion rates have kept pace with SLR for thousands of years, but there is limited spatial and temporal frequency of this data [9]. Mangrove sediment records can also indicate large storm events by the thickness of sand layers [39]. Because mangroves are also major producers and sequesters of organic carbon, radiometric dating can also provide evidence of sea level when the peat was formed and SLR can be reconstructed using multiple dates $[9,25,40-45]$.

\section{The Need for Improved Modelling}

Tropical and sub-tropical regions, where mangroves exist, are at a significant risk from the combined anthropogenic and climate change effects. Yet, current modelling of mangrove sedimentation is insufficient to account for the hydro-geomorphic connection between mangrove sediment accretion and upstream hydrology. Additionally, mapping techniques, although rapidly improving, have limited precision to track sediment accretion, subsurface processes, stormwater infrastructure, or to quantify compound coastal and riverine flooding $[4,30,46]$. The complex interrelations between regional to local scales of fluvial, coastal, and sedimentation processes and the compounding and amplifications of these processes due to climate change and anthropogenic activity provides an added constraint to current modelling efforts [4,9,30-32].

Furthermore, most hydrologic models have been created in and primarily for temperate regions with extensive hydrometeorological monitoring networks. Particularly in developing regions in the tropics, hydrometeorological monitoring networks are often spatially and temporally limited to fully identify the upstream hydrology and sediment fluxes that affect mangrove estuaries [47,48]. Furthermore, upstream modifications, such as impervious surface, altered stormwater conveyance, and dams are not adequately represented [49]. Consideration should also be given to the accuracy of limited data or single-point observations, modelling, and numerical values that are extrapolated spatially and temporally to represent upstream 
fluvial, coastal, and sediment processes. There are also critical knowledge gaps between small-scale mechanisms of mangrove sediment flux and vulnerability in relation to large scale processes $[4,11,50]$.

\section{Conclusion}

Although mangroves are threatened by SLR, the persistence of mangroves show they are reasonably capable of adapting and responding; however, anthropogenic changes along the coast and inland represent a greater threat to mangroves $[9,25]$. Global monitoring of riverine sources is needed in addition to limits to mass tourism, deforestation, and upstream land use change [22]. Land should also be provided for mangroves to retreat landward [9]. Rapid development and expansion of urbanization further exacerbates negative effects of sedimentation and loss of mangroves, thus, there is a need for improved monitoring as well as an integrated modelling approach for better management decisions. The lack of integrated flood modelling leaves local communities ill-prepared to make effective management decisions [30]. Increased collaboration is needed between researchers, local, regional, and international agencies, and local communities to ensure resiliency of coastal areas, including mangroves, and connected land and water upstream.

\section{References}

1. Giri C, Ochieng E, Tieszen LL, Zhu Z, Singh A, et al. (2011) Status and distribution of mangrove forests of the world using earth observation satellite data. Global Ecology and Biogeography 20(1): 154-159.

2. Duke NC, J-O Meynecke, S Dittmann, AM Ellison, K Anger, et al. (2007) A world without mangroves? Science 317: 41-42.

3. Swales A, G Reeve, DR Cahoon, CE Lovelock (2019) Landscape Evolution of a Fluvial Sediment-Rich Avicenna marina Mangrove Forest: Insights from Seasonal and Inter-annual Surface-Elevation Dynamics. Ecosystems 22: 1232-1255.

4. Webb Edward L, Friess Daniel A, Krauss Ken W, Cahoon Donald R, Guntenspergen Glenn R, et al. (2013) A global standard for monitoring coastal wetland vulnerability to accelerated sea-level rise (2013) Nature climate change 3: 458-465.

5. Blankenspoor B, S Dasgupta, G Lange (2017) Mangroves as a protection from storm surges in a changing climate. Ambio 46: 478-491.

6. Ragavan P, Mandal RN (2018) Status of Indian Mangroves. Oceanography and Fisheries. Oceanography \& Fisheries Open Access Journal 7(4): 555718

7. Chowdhury RR, Uchida E, Chen L, Osorio V, Yoder L (2017) Anthropogenic Drivers of Mangrove Loss: Geographic Patterns and Implications for Livelihoods. In: Rivera-Monroy V, Lee S, Kristensen E, Twilley R (eds.) Mangrove Ecosystems: A Global Biogeographic Perspective, Springer

8. Sasmito SD, D Murdiyarso, DA Friess, S Kurnianto (2016) Can mangroves keep pace with contemporary sea level rise? A global data review. Wetlands Ecology and Management 24: 263-278.

9. McIvor AL, Spencer T, Möller I and Spalding M (2013) The response of mangrove soil surface elevation to sea level rise. The Nature Conservancy and Wetlands International.

10. Geist HJ, Lambin EF (2002) Proximate causes and underlying driving forces of tropical deforestation. Bioscience 55(2): 143-150.
11. WWF (2020) Sediment Flow in the Context of Mangrove Restoration and Conservation: A Rapid Assessment Guidance Manual.

12. Sidik F, Neil D, Lovelock C E (2016) Effect of high sedimentation rates on surface sediment dynamics and mangrove growth in the Porong River, Indonesia. Marine pollution bulletin 107(1): 355-363.

13. BM Janssenn-Stelder, PGEF Augustinus, WAC van Santen (2002) Sedimentation in a coastal mangrove system, Red River Delta, Vietnam. Proceedings in Marine Science. 5: 455-467.

14. Besset M, Anthony EJ, Bouchette F (2019) Multi-decadal variations in delta shorelines and their relationship to river sediment supply. An assessment and review. Earth-Science Review 193: 199-219.

15. Best J (2018) Anthropogenic stresses on the world's big rivers. Nature Geoscience 12: 7-11.

16. Giri C, Zhu Z, Tieszen LL, Singh A, Gillette S, et al. (2008) Mangrove forest distributions and dynamics (1975-2005) of the tsunami-affected region of Asia. Journal of Biogeography 35 (3): 519-528.

17. Valiela I, Bowen JL and York JK (2001) Mangrove forests, one of the world's threatened major tropical environments. Bioscience 51: 807815.

18. Alongi D M (2002) Present state and future of the world's mangrove forests. Environmental Conservation 29(3): 331-349.

19. Ellison JC (2009) Geomorphhology and sedimentology of mangroves. In: Perillo G, Wolanski E, Cahoon D and Brinson M (eds.) Coastal wetlads: An integrated ecosystem approach, Elsevier, Pp: 565-591.

20. Ellison JC (1999) Impacts of sediment burial on mangroves. Marine Pollution Bulletin 37(8): 420-426.

21. Thom BG (1967) Mangrove ecology and deltaic geomorphology, Tabasco, Mexico. Journal of Ecology 55: 301-343.

22. Ana Cano-Ortiz, Carmelo Maria Musarella, José Carlos Piñar Fuentes, Carlos Jose Pinto Gomes, Sara Del Rio, et al. (2018) Analysis of the Conservation of Central American Mangroves Using the Phytosociological Method. Mangrove Ecosystem Ecology and Function.

23. Anthony EJ (2015) Wave influences in the construction, shaping and destruction of river deltas: A review. Marine Geology 361: 53-78.

24. Whelan KRT, Smith TJ, Cahoon DR, Lynch JC, Anderson GH (2005) Groundwater control of mangrove surface elevation: Shrink and swell varies with soil depth. Estuaries 28: 833-843.

25. Woodroffe CD, K Rogers, KL McKee, CE Lovelock, IA Mendelssohn, et al. (2016) Mangrove Sedimentation and Response to Relative Sea-Level Rise. Annual Review of Marine Science. 8: 243-266.

26. Ellison JC (2008) Long-term retrospection on mangrove development using sediment cores and pollen analysis: A review. Aquatic Botany 89: 93-104.

27. Ellison JC (1991) Mangrove ecosystem collapse during predicted sea level rise. Journal of Coastal Research 7(1): 151-165.

28. Saad S, Husain ML, Yaacob R, Asano T (1999) Sediment accretion and variability of sedimentological characteristics of a tropical estuarine mangrove: Kemaman, Terengganu, Malaysia. Mangroves and Salt Marshes 3(1): 51-58.

29. NOAA (2020) What contributes to coastal flooding?

30. Pietrafesa Leonard J, Honguyan Zhang, Shaowu Bao, Paul T Gayes and Jason 0 Hallstrom (2019) Coastal Flooding and Inundation and Inland Flooding due to Downstream Blocking. Journal of Marine Science Engineering 7: 336 .

31. Ganguli Poulomi and Bruno Merz (2019) Extreme Coastal Water Levels Exacerbate Fluvial Flood Hazards in Northwestern Europe. Scientific Reports 9: 13165. 
32. Ellison JC (1993) Mangrove retreat with rising sea-level, Bermuda Estuarine, Coastal and Shelf Science 37: 75-87.

33. Cahoon DR, Reed DJ, Day JWJ, Steyer GD, Bourmans RM, et al. (1995) The influence of Hurricane Andrew on sediment distribution in Louisiana coastal marshes. Journal of Coastal Research Special Issue 21: $280-294$.

34. Dunn FE, Darby SE, Nicholls RJ, Cohen S, Zarfl C, et al. (2019) Projections of declining fluvial sediment delivery to major deltas worldwide in response to climate change and anthropogenic stress. Environmental Research Letters 14: 084034.

35. Cahoon DR, Hensel PF, Spencer T, Reed DJ, McKee KL, et al. (2006) Coastal wetland vulnerability to sea-level rise: wetland elevation trends and process controls. In: Verhoeven JTA, Beltman B, Bobbink R, Whigham DF (eds.) Wetlands and Natural Resource Management Ecological Studies, Springer-Verlag, Berlin, Heidelberg, Germany Pp: 271-292.

36. Cahoon DR, Hensel PF, Rybczyk J, McKee KL, Proffitt CE, et al. (2003) Mass mortality leads to mangrove peat collapse at Bay Islands, Honduras after Hurricane Mitch. Journal of Ecology 91(6): 1093-1105.

37. McKee KL, McGinnis II TE (2002) Hurricane Mitch: Effects on mangrove soil characteristics and root contributions to soil stabilization: USGS Open File Report 2003-178 57.

38. Haque A, Kay S, Nicholls RJ (2018) Present and Future Fluvial, Tidal and Storm Surge Flooding in Coastal Bangladesh. In: Nicholls R, Hutton C, Adger W, Hanson S, Rahman M, et al. (eds.) Ecosystem Services for Well-Being in Deltas. Palgrave Macmillan, UK.

39. McCloskey TA, K Liu (2012) A 7000 year record of paleohurricane activity from a coastal wetland in Belize. The Holocene 23(2): 278-291.

40. Briethaupt JL, Smoak JM, Smith III TJ, Sanders CJ, Hoare A (2012) Organic carbon burial rates in mangrove sediments: Strengthening the global budget. Global Biogeochemical Cycles 26(3).

41. Ezcurra P, Ezcurra E, Garcillan PP, Costa MT, Aburto-Oropeza O (2016) Coastal landforms and accumulation of mangrove peat increase carbon sequestration and storage. Proceedings of the National Academy of Sciences of the United States of America. 113(16): 44044409.

42. Freeman E, Skinner LC, Waelbroeck C, Hodell D (2016) Radiocarbon evidence for enhanced respired carbon storage in the Atlantic at the Last Glacial Maximum. Nature Communications 7:11998.

43. Fairbanks RG, Mortlock RA, Chiu T, Cao L Kaplan A, Guilderson TP, et al (2005) Radiocarbon calibration curve spanning 0 to 50,000 years BP based on paired $230 \mathrm{Th} / 234 \mathrm{U} / 238 \mathrm{U}$ and $14 \mathrm{C}$ dates on pristine corals. Quaternary Science Reviews 24 (16-17): 1781-1796.

44. Stuiver M, Reimer PJ, Braziunas TF (1998) High-precision radiocarbon age calibration for terrestrial and marine samples. Radiocarbon 40(3): 1127-1151.

45. MacDonald GM, Beukens RP, Kieser WE (1991) Radiocarbon dating of limnic sediments: a comparative analysis and discussion. Ecology 72(3): 1150-1155.

46. Paprotny D, Vousdoukas MI, Morales-Napoles O, et al. (2020) PanEuropean hydrodynamic models and their ability to identify compound floods. Natural Hazards 101: 933-957.

47. Calderon $\mathrm{H}$ and Uhlenbrook S (2016) Characterizing the climatic water balance dynamics and different runoff components in a poorly gauged tropical forested catchment, Nicaragua. Hydrological Sciences Journal 61(14).

48. Sivapalan M, et al. (2003) IAHS Decade on Predictions in Ungauged Basins (PUB), 2003-2012: Shaping an exciting future for the hydrological sciences. Hydrological Sciences Journal 48 (6): 857-880.

49. Bevacqua E, Vousdoukas M I, Shepherd T G, and Vrac M (2020) Brief communication: The role of using precipitation or river discharge data when assessing global coastal compound flooding, Natural Hazards and Earth System Sciences 20: 1765-1782

50. Syviski JPM, JD Milliman (2007) Geology, geography, and humans battle for dominance over the delivery of fluvial sediment to the coastal ocean. The Journal of Geology 115(1): 1-19.

\section{Your next submission with Juniper Publishers} will reach you the below assets

- Quality Editorial service

- Swift Peer Review

- Reprints availability

- E-prints Service

- Manuscript Podcast for convenient understanding

- Global attainment for your research

- Manuscript accessibility in different formats

( Pdf, E-pub, Full Text, Audio)

- Unceasing customer service

Track the below URL for one-step submission https://juniperpublishers.com/online-submission.php 